\title{
ON SARTRE'S EXISTENTIALISM
}

\author{
Keiji NISHITANI \\ Kyoto University
}

In the previous section I mentioned God, but today it has become a question to begin with whether there is a God or not. Not that atheism did not exist in olden times, but atheism today has a special characteristic which makes it different from what it was previously. Atheism today has been raised to the rank of a substitute for religions with their Deities; it tries to provide an ultimate basis for human existence and to point out the ultimate telos of human life. Atheisn comes forth with the assertion that it alone is the proper standpoint today which is truly adequate to a modern man. We find such a characteristic as this in Marxism and in atheistic existentialism, of which Sartre's existentialism in the form of humanism is an example.

Sartre says in his "L' Existentialisme est un humanisme," "Existentialism is nothing else than an attempt to draw all the consequences of a coherent atheistic position." "God does not exist, and we have to face all the consequences of this." Already in the last century, many thinkers thought that God had become a useless, out-of-date hypotheses, and that they could set up from humanism a better system of values which might provide norms a priori for society, morality, culture and so on. This was simply an optinistic humanism, one of the most prominent expressions of which we find in Feuerbach's philosophy of "Anthropology." But the existentialistic humanism of our time is a humanism which "thinks it very distressing that God does not exist." Sartre quotes from Dostoievsky; "If God didn't exist, everything would be permitted," and says that this is the very starting point of existentialism. He thinks that the foundation of human existence is nothingn $\epsilon$ s. The fact that man cannot find anything to depend upon either within or outside himself, is, for him, the basis of existentialism. The reason that existentialism is established on the basis of atheism is that nothing is found at the foundation of our being itself and that we come, prereflectively, to an awarencss of this "nothing," as the foundation of our self-being and the basis of our subjectivity. Existentialism is subjectivism in the sense that man cannot pass beyond human subjectivity. Atheism, that is, the assertion that man cannot have anything to depend upon either within or outside himself, appears, in the form of existentialism, as a deepening of man's subjectivity.

But from that position, Sartre enters into a relation with the Cartesian ego. According to him, in the position of this ego we have the absolute truth of evident consciousness, and outside of this, there is no truth which we might take as a starting point. In the case of Descartes, although he arrived at the ego of cogito ergo sum and started from it, this ego was after all something which could not help again to postulate beyond istelf God and His veracity. For Sartre, the ego is subjectivity set up on "nothing." The existence of the self as a "res cogitans" is apperceived on the basis of nothingness. While it is based in the same way on the apperception of the ego, the ground of the existence of this ego has 
changed from God to nothingness, from theism to atheism. We can perceive in this change the distance which modern man has covered since he began to follow his own way of independent subjectivity. The fact that there is nothing to depend upon either within or outside, signifies for Sartre the very freedom of human existence. Human existence, as an existence based on nothingness and thrown from nothingness into an actual situation, cannot be other than free. Man is "condemned" to be free. With this freedom, each individual chooses in his actual situations his own mode of existence; he chooses himself. In all his actions, he throws himself before himself as "a series of undertakings" and in that way chooses himself. His existence consists in "projet." Existence means that a human being, thrown into his factual situation, is at the same time ceaselessly going out of his own "being" and is suspended in nothingness. This constitutes freedom. Thus alone it is possible for him to act. Sartre says that the the reason that he calls his existentialism a humanism is that a man who chooses and creates himself at the same time creates an image of man such as he believes he ought to be. In choosing himself "he is at the same time a legislator deciding for the whole of mankind." If he chooses and decides, for example, to marry and to have children, in his decision he not only chooses himself, but also indicates how humanity as a whole ought to be; he has established an "image of man." The act of choice always implies responsibility to oneself and to the whole of mankind as well. Therefore, existentialism is a humaism, he says. According to the Christian tradition, man is created in the image of "God," which image constitutes his essence and precedes ontologically his existence. But in Sartre's atheism, which sees "nothing" at the foundation of the self, it is a natural consequence that the concept of God's image is discarded and an image of man, in which his existence is thought to precede his essence, is established.

Such a standpoint reveals a conclusion naturally drawn by modern man who set out from the self-consciousness of the Cartesian ego. It can be said that herein the "problematical" which was hidden from the start in that ego has become manifest in a clear-cut form. As I have said previously, even though cogito crgo sum is the most directly real fact, the evidence of that fact cannot authenticate modern man's ego being derived from it, as it would seem at first glance. A most subtle and easily misleading problem is lurking herein. The status of "ego" consists in "I think" being thought from the standpoint of "I think." I consists in a duplication of "I think." Here subjectivity appears taking the form of a self shut up within itself, which means that the self is bound by itself in such a way that cannot extricate itself from itself. There is a characteristic in the very existence of this self, which may be called "clinging to oneself" or "being bound by one's own hands with one's rope." There is a demand concealed within the depth of such a self for liberation from itself. This liberation-namely, the true emergence of the reality of "I think" and "I am"- -is first possible on the level where the above mentioned duplication of "I think" has been broken and the field of consciousness and self-consciousness passed through. Subjectivity also can be revealed for the first time as original subjectivity at the point where the framework of the Cartesian ego has burst.

Sartre says that his theory "is the only theory which gives man dignity, the only one which does not reduce him to an object." We can well appreciate his purpose, but as I said before, so long as we do not open up a horizon which transcends wholly the field of 
the self-conscious ego, there always remains in us some residuum of our inveterate habit of representing our own self as an object, no matter how we think of subjectivity. Moreover, although his theory appears to ensure the dignity of man as it is expressed in his freedom and independence, I think the real dignity of man can be establish only in the "reborn man"- or the "new man" - that emerges in us, when we die to our self and resuscitate to our self, cutting through the "nothing" in doing so. Sartre also says that existence of man consists of "projet," that is, of its continuously transcending itself and going out of itself. He recognizes, therefore, an "ecstatic" transcendence. This transcendence is not transcendence in the sense that God is transcendent. It means that there is "nothing" at the foundation of the self-being. To go continuously out of oneself in choosing one's own existence is to make this nothingness a spring-board, so to speak. But so long as he places subjectivity in the position of the Cartesian ego, this is not even the "death" spoken of by Heidegger. The being of this ego is not "being unto death." Neither is it the previously mentioned "great Death" which was said to be the field of "nothing" opened in the great Doubt; because the great Doubt is no other than the bankruptcy of the Cartesian ego. Still more, it is not Buddhistic "sunyata" ("nothingness or emptiness"). Nothingness in Buddhism is "non-self," while Sartre's nothingness is, in spite of its transcendence, still thought of as immanent in the ego, a sort of transcendence glued to the ego, as it were. Although he considers it the foundation of the subject, it is still considered like a wall projected in the base of the ego, or like a springboard on which the ego is standing. His nothingness is turned into a basic factor that shuts the ego up within itself. Here, the cgo has a partition of nothingness at its bottom, and becomes a vast and desolate cave, so to speak. It reminds us of what men of Zen used to call "livelihood in the Black Mountain" or "living in the Demon's Cavern" _ that is, to live inside the cave of the self-conscious ego with its "subjective" nothingness opened at its base. So far as this "nothingness" is still set up as something called nothingness at the base of our existence, it does not yet go beyond "the perversely-grasped Sunyata (Emptiness)" which is rebuked by Buddhism. Our existence, here, is an existence "attached to Emptiness": and its subjectivity, although deepened basically, is still "demonic." The self which sets up this "nothingness" is, just in doing so, bound and captured by that nothingness. While this existence on "nothing" seems to pass through a denial of "self-attachment" it is, in turn, a self-attachment in higher potency and in subtler concealment. This nothingness appears, of course, as negativity, as negation of "being" in general; but so long as it presents itself as an object of consciousness, and so also in the form of representation-or, (what means the same), so long as it is an object of a basic attachment,-it still retains a certain character of being. The "nihil" usually spoken of is somethinglike this. It cannot truly be the "absolute negation" of the self and all things, because it hides behind it a self that has a representation (idea) of it and in that way is basically attached to it, and through this, it becomes itself a kind of "being." Also it can not truly be the "absolute affirmation" of the self and all things, because it is not the field on which all things are present in reality as they are. The "nothingness" so-called here is merely the void, the "nihil," that turns everything into non-reality. This is that which in Buddhism came to be called the sunyata (emptiness) of "the nihilating view-point." Buddhism stresses rather the Absolute Sunyata that negates 
even such nihilating sunyata. In this absolute Sunyata, there can be transcended, for the first time, both the field of consiciousness where our self and all things are viewed as positive reality (internal or external), and the nothingness which is seen at their foundation; that is, both the simply negative attitude in all sorts of nihilism " the nihilating view" in Buddhistic terms) and the simply positive attitude in all sorts of positivism and naive realism ("the view of constancy") are transcended. Both the self which is the attacher and the "thing" that are attached to are nihilated and made "empty." All are truly "empty." But that all things are nihilated and empty means here that all things are just present in their original reality. This is True Suchness. And it is also non-attachment. To see, like Sartre, that there is "nothing" at the ground of one's existence means that there is no ground for the self. But here, the nothingness of "there is no ground" is still standing before the self like a wall and turns into a kind of ground - that is, turns into there being a ground. Only Absolute Emptiness is the truly groundless (Ungrung). Here all things, a flower and a stone, nebulas and galactic systems, - even life and death - present themselves as bottomlessly real, as bottomlessly such as they are. True freedom lies in the "bottomless" such as this; while, on the contrary, Sartre's "freedom" is still bondage, because the "nothing" on which it is established is such a kind of nothingness as still has a shadowy projection of the "ego" wedged into like a stake, the self being bound to it. (This is what is meant by "attachment.") What he has grasped can be called freedom, but more fundamentally, it is rather bondage.

Sartre says, "There is no reality except in actions" and, "At heart, what existentialism shows is the connection between the absolute character of free involvement, by virtuc of which every man realizes himself in realizing a type of mankind, an involvement always comprehensible in any age whatsoever and by any person whomsoever, and the relativeness of the cultural ensemble which may result from such a choice; it must be stressed that the relativity of Cartesianism and the absolute character of Cartesian involvement go together." I think the meaning of this will be understood from what I said previously about his thought. The question is, from what plane are the actions spoken of here to be done, and from what plane is the realization of oneself and "a type of mankind" to be realized. In order that an action truly be reality, it must not be done from such sort of nothingness as Sartre speaks of. When he says, "Each of us performs an absolute act in breathing, eating, sleeping, or behaving in any way whatever. There is no difference between being free and being absolute," it sounds as if they were the words of a follower of Zen, but the fact that such actions as dressing and eating are "absolute actions" cannot really be affirmed and confirmed from his standpoint. Neither is the realization of a "type of mankind" possible on the level of humanism which he speaks of, but it must mean the realization of a "new man," which accrues from the absolute negation of "man." An action is able to become truly "absolute" only as arising from the plane which is opened up when we breakthrough the cave of the ego, and through the wall of the "nothingness" at the base of the ego, too; - that is, only when it is an action that comes to realize itself from the yonder side (or rather from this side) of field of consciousness and self-consciousness, the field of "ego," and when it ceases to be "my" or"your" action, although it is also the same I or you who then acts. 
It is natural that Santre's existentialism, which rests on a Cartesian subjective ego, should give rise to a criticism of materialism, which is its antipode. In Santre's book which we mentioned, there is a discussion with a certain Marxist in the supplement, and there it is asserted, from the standpoint of materialism, that the first reality is the natural reality, of which the human reality is only a function, and that natural conditions are the prime reality. From such a point of view, it is not possible to explain the subjectivity of our self, and the criticism itself does not seem to have been raised with sufficient understanding in regard to man's "existence" which Sartre asserts. But it cannot be denied also that the reason that such a criticism has appeared lies in Sartre himself. So long as we do not transcend the field of the fundamental separation between subject and object, there arises of necessity an opposition between the standpoint of viewing the object from the side of subject taken as basic, and that of considering the subject from the side of object which is taken as the basis. And in either case, as I said previously, we do not truly and really reach the reality of the self or the reality of things.

Keiji Nishitani (西谷㤵治 1900- ) Graduated from Kyoto Univ. in 1924, 1935- Assist. Prof., 1942, Doctor of Letters, 1943- Prof. of Philosophy, Kyoto University.

(Reproduction of the author's "What is religion?" Chapt.V in "Philosophical Studies of Japan," Vol.2, 1960, compiled by Japanese Commission for Unesco and published by Japan Society for the Promotion of Science, with their agreement.) 